\title{
ANÁLISE SOBRE A POSSIBILIDADE DE INTERPOSIÇÃO DE RECURSO ANTE A OMISSÁO JUDICIAL EM PEDIDOS DE URGÊNCIA
}

\author{
ANALYSIS ABOUT THE POSSIBILITY OF FILING AN APPEAL AGAINST \\ THE JUDICIAL OMISSION ON REQUESTS FOR EMERGENCY
}

Alexandre Freire Pimentel ${ }^{1}$ (이

I Universidade Católica de Pernambuco (UNICAP),

Recife, PE, Brasil. Doutor em Direito. E-mail: alexandrefreirepimentel@gmail. com

\begin{abstract}
Resumo: Através do método histórico e bibliográfico, o presente artigo objetiva analisar o cabimento de recurso contra omissóes judiciais na apreciação de pedidos de tutelas de urgência, na sistemática do atual código de processo civil. Pretende-se demonstrar que quando o juiz não aprecia imediatamente uma tutela de urgência, em verdade, ele denega a pretensão e que é possível interpor recurso nessa situação.

Palavras-chave: Tutelas de urgência. Omissão judicial. Recurso. Cabimento.

Abstract: Through the historical and bibliographic method, this research aims to analyze the possibility of using the appeal against the judicial omission in emergency's requests, based on the current civil procedure law system. It intends to demonstrate that when the judge does not immediately consider an emergency guardianship, it, in fact, denies the claim and that it is possible to appeal in this situation.
\end{abstract}

Keywords: Emergency's requests. Omission judicial. Appeal. Suitability.

DOI: http://dx.doi.

org/10.31512/rdj.v20i37.47

Recebido em: 17.01.2019

Aceito em: 10.03.2020 


\section{Introduçáo}

Do ponto de vista metodológico, o principal problema abordado no presente artigo consiste na análise da possibilidade, ou náo, da interposiçáa de agravo de instrumento contra situaçóes processuais ocorridas no primeiro grau de jurisdiçãa nas quais o magistrado não aprecia, imediatamente, pedidos de tutela provisória de urgência.

A "hipótese" metodológica desta investigação consiste na suposição de que tais situaçóes omissivas traduzem, na verdade, uma modalidade de decisão interlocutória denegatória do requerimento de tutela provisória de urgência, porquanto a postergação da apreciação representa um indeferimento fático que pode, inclusive, ensejar a perda de objeto da demanda em razão da irreversibilidade dos efeitos derivados da inércia judicial.

Nesse contexto, pretende-se esclarecer se o ato judicial que, em vez de apreciar o pleito de urgência, resolve determinar a citação da parte ré para deliberação subsequente, deve ser interpretado como um despacho ou se consiste, de fato, em verdadeira decisão interlocutória de conteúdo omissivo-indeferitório desprovida de fundamentação e, portanto, nula (CPC-2015, art. 489). Pretende-se, assim, através da análise históricocrítica do recurso de agravo, associada ao método de pesquisa bibliográfico, verificar a possibilidade de impugnação de tais decisões através do recurso de agravo de instrumento.

Analisar-se-á, também, os desdobramentos da situação no âmbito do segundo de grau de jurisdição, isto é, quando também o relator do agravo de instrumento adota a mesma postura omissiva diante de situação processual que impóe pronunciamento judicial imediato.

Assim, uma vez identificado o objeto da pesquisa e a problematização respectiva, o objetivo do presente trabalho consiste em perfazer um juízo crítico sobre as posiçóes contrapostas na doutrinária e na jurisprudência construídas sob a égide do CPC-1973 e diagnosticar os aspectos processuais que se apresentarão compossíveis com a nova sistemática introduzida pelo código de 2015.

\section{Origens históricas do recurso de agravo e suas espécies}

A origem do recurso de agravo remonta ao direito medieval português. No início, o recurso de apelação tinha por objeto o reexame de sentenças definitivas e interlocutórias (SANTOS, 1985, p. 126). Contudo, algumas sentenças eram proferidas por autoridades judiciárias de segunda instância, corregedores do reino português, juízes das Índias, ou até mesmo as do próprio rei que tinha competência para decidir as querimonias (queixas contra as sentenças dos juízes locais), contra as quais não se admitiam recursos (ALVIM, 1996, p. 100). 
Porém, as partes sucumbentes, inconformadas com a decisão desfavorável, insistiam pela reforma das decisóes judiciais. E o conhecimento dessas súplicas originou o agravo ordinário (NEVES, 1996, p. 15). Este, por sua vez, inspirou-se na suplicatio romana e representa o primeiro agravo da história do direito processual luso-brasileiro. Ocorre que no reinado de Afonso IV, a apelação deixou de ser cabível contra sentenças interlocutórias, salvo em hipóteses excepcionais. As sentenças interlocutórias passaram a ser impugnadas através de querimonias dirigidas aos juízes de instância superior ou ao próprio rei. Então, logo em seguida, no reinado de D. Duarte essas queixas transformaramse no recurso de agravo de instrumento (SANTOS, 1985, pp. 124/125).

Em sucessivo à criação do agravo de instrumento, surgiu o agravo de petição, cujo processamento dava-se nos próprios autos do processo, ainda no primeiro grau de jurisdição. Depois, surgiu o agravo no auto do processo, admitido contra decisóes proferidas no curso da demanda referentes à ordem do procedimento, desde que capazes de influenciarem no julgamento final. Na vigência das Ordenaçōes Filipinas surgiu outra espécie de agravo: o agravo de ordenação mal guardada cujo objetivo era preservar a garantia do cumprimento das formalidades extrínsecas do procedimento (SANTOS, 1985, pp. 125).

Com a independência do Brasil, restaram cinco espécies de agravos: ordinário, de instrumento, de petição, no auto do processo, e de ordenação mal guardada. Os dois primeiros a serem abolidos foram: o agravo ordinário, através da Disposiçâo Provisória de 29 de novembro de 1832; e o de ordenaçáo mal guardada, pelo Reg. no 143, de 15 de março de 1842. Mas a mesma Disposiçáo Provisória, de 1832, que pôs fim ao agravo ordinário, transformou os agravos de instrumento e de petiçáo em agravo no auto do processo. Entretanto, esses dois agravos revogados voltaram à cena processual brasileira, ainda em 1841. Em sequência o Regulamento 737, de 1850, que passou a reger o processo comercial, só admitiu os agravos de petição e de instrumento.

Mas, como o Decreto $\mathrm{n}^{\circ} 763$, de 19 de setembro de 1890, determinou que se aplicasse ao processo civil o Regulamento 737/1850, o agravo no auto do processo foi extinto. Em seguida, em consideração ao princípio federativo, o processo civil brasileiro passou a ser de competência dos Estados-membros. O primeiro código de processo civil federal (de 1939) ressuscitou o agravo no auto do processo. Em 1974, passou a viger o CPC-1973, que, por sua vez, também procedeu a alteraçóes no regime dos agravos. Para substituir o agravo no auto do processo foram instituídos o agravo retido e o agravo interno (SANTOS, 1985, pp. 124/125). Passemos à análise das alteraçôes introduzidas pelo CPC-2015 no regime dos agravos. 


\section{$3 \mathrm{O}$ agravo interno no $\mathrm{CPC}-2015$ : um réquiem para o agravo regimental}

No regime do CPC-1973, o agravo interno previsto em lei federal, também denominado por parte da doutrina de agravo legal, agravinho, agravo de mesa, ou inominado, tinha o seu cabimento limitado às decisóes singulares proferidas pelos relatores de segunda instância ou de tribunais superiores. Sobre o tema Eduardo Talamini (2002, p. 184) ponderou:
O nome que se dê à medida - "agravo interno", "regimental", agravinho" - é irrelevante, pois a essência do "agravo" interposto no âmbito interno do tribunal contra decisóes isoladas de algum de seus membros é sempre a mesma: trata-se de mecanismo destinado a levar ao colegiado a decisão individualmente adotada.

Porém, não contra qualquer decisão do relator, mas, apenas, em face daquelas de natureza terminativa (denegatória de seguimento, de não provimento, bem como de concessão de provimento), isto é, não cabia contra decisóes monocráticas interlocutórias de segundo grau ou de tribunal superior, mas só das que resolviam o recurso ou o incidente de conflito de competência (SOUZA, 2014, p. 216). Contra as decisões monocráticas interlocutórias o recurso cabível era outro tipo de agravo: o regimental.

$\mathrm{Na}$ sistemática de 1973, portanto, o agravo interno representava, na verdade, um gênero que abrangia duas espécies: o agravo previsto em lei federal (denominado de agravo legal); e o agravo instituído pelos regimentos internos dos tribunais (por essa razão, intitulado de agravo regimental). Este último foi contemplado num trabalho de Egas Moniz de Aragão (1961, p. 183), sempre citado na doutrina nacional, no qual o agravo regimental é concebido como um meio de promoção da integração do tribunal. Ocorre que essas duas espécies possuem essa mesma finalidade integrativa, porém, não, precisamente, de integrar o "tribunal", mas o órgão colegiado ao qual pertence o relator que proferira a decisão monocrática.

Eram hipóteses de cabimento de agravo interno-legal no CPC-1973: 1a - no julgamento monocrático do conflito de competência, quando havia jurisprudência dominante do tribunal sobre a questão suscitada, caso em que o relator podia decidir de plano o conflito, cabendo agravo, no prazo de cinco dias, contado da intimação da decisão às partes, para o órgão recursal competente (CPC, art. 120); $2^{\mathrm{a}}$ - em face da decisão monocrática que não admitia embargos infringentes, hipótese que desafiava agravo, em cinco dias, para o órgáo competente para o julgamento do recurso (CPC, art. 532); $3^{\mathrm{a}}$ - da decisão do relator que não admitia o agravo de instrumento interposto contra a decisão denegatória de recurso extraordinário ou especial, caso que admitia agravo no prazo de cinco dias (CPC, art. 545); 4a - quando o relator negava seguimento a recurso manifestamente inadmissível, improcedente, prejudicado ou em confronto com súmula ou com jurisprudência dominante do respectivo tribunal, do Supremo Tribunal Federal, ou de Tribunal Superior (CPC, art. 557). 
Pois bem, no CPC-2015, o art. 1.021 previu que: "Contra decisão proferida pelo relator caberá agravo interno para o respectivo órgão colegiado, observadas, quanto ao processamento, as regras do regimento interno do tribunal”. Este agravo é interno, porquanto sua interposição e julgamento não exorbita o âmbito do órgão colegiado ao qual pertence o relator. E se diferencia do agravo regimental em razão de sua fonte: é instituído por lei federal, ao passo que o regimental é criado por ato administrativo, em preclaro malferimento ao princípio da legalidade recursal, considerando que "recurso" é matéria de natureza indiscutivelmente processual, logo, nos termos do art. 22, I, da Constituição Federal, somente a União, através do Congresso Nacional, pode legislar sobre recursos.

No novo código, o fato de o agravo interno-legal (previsto no art. 1.021) ser interponível “... contra decisão proferida pelo relator...” significa dizer que o seu cabimento foi sensivelmente ampliado, porquanto é admissível tanto contra decisóes terminativas quanto interlocutórias do relator, por isso, representa um verdadeiro réquiem ao agravo regimental, já que as hipóteses previstas em regimento interno de tribunais foram, todas elas, abrangidas pela característica generalista do art. 1.201 do CPC-2015.

Tal conclusão parece logicamente irretorquível, contudo não é a primeira vez que uma lei federal previu o cabimento de agravo interno-legal para hipóteses coincidentes com as do agravo regimental, tanto que Theotonio Negráo (1999, p. 591) chegou a afirmar: “... o antigamente chamado agravo regimental deixou de ser regimental, por previsão em lei atualmente". Não obstante, a jurisprudência, ainda assim, manteve o agravo regimental como espécie recursal diferenciada. Porém, a situação adotada pelo art. 1.021 do CPC-2015, simplesmente, eliminou qualquer utilidade de previsão regimental acerca da recorribilidade das decisóes interlocutórias dos relatores, considerando que para todas elas o recurso adequado será o agravo interno-legal, sejam tais decisóes de natureza terminativa ou de índole interlocutória.

Essa observação éimportante não apenas do ponto de vista acadêmico, mas, também quanto ao aspecto prático, pois há Estados nos quais as leis de organização judiciária preveem a incidência de custas, ou seja, condicionam o conhecimento do agravo internolegal ao preparo. O CPC-2015, por sua vez, não isentou o agravo interno do pagamento do preparo, como fez, por exemplo, em relação aos embargos declaratórios (art. 1.023). Assim, e considerando que a parte final do art. 1.021 manda que se observem as regras do regimento do tribunal no tocante ao processamento do agravo, conclui-se que se a lei estadual previr a exigência do preparo o conhecimento desse recurso fica condicionado ao seu recolhimento. E como o agravo interno-legal passou a ser interponível para desafiar qualquer decisão monocrática do relator, as decisóes interlocutórias que antes eram desafiadas por agravo regimental, o qual não exige o preparo, agora passaram a depender do que dispuser a legislação estadual de regência. 
Quanto ao procedimento do agravo interno-legal, o CPC-2015 inovou no tocante à exagerada ampliação do prazo recursal, que passou de cindo dias corridos para quinze dias úteis. Ademais, instituiu o direito de contrarrazóes e o dever de inclusão em pauta. Tais medidas, por um lado, representam maior garantia de qualidade dos fundamentos dos recorrentes, mas, por outro, sem a mais mínima dúvida, constituem entraves à celeridade processual. Ademais, a previsão constante do $\$ 3^{\circ}$, do art. 1.201, é simplesmente inócua, pois ao declarar que: "É vedado ao relator limitar-se à reprodução dos fundamentos da decisão agravada para julgar improcedente o agravo interno", tenta obrigar o tribunal a perfazer nova argumentação jurídica acerca dos fundamentos da decisão monocrática. Sobre o problema, Bobbio, Matteucci e Pasquino (1983, p. 1161) advertem que quando a lei tenta impor uma forma de fundamentação, em verdade, a imposição não passa de um dever 'aparente', vejamos:

$\mathrm{Na}$ prática, porém, segundo se objeta, isso é um dever apenas aparente: é um fato indiscutível para os estudiosos e reconhecido por muitos juízes (por ex., Cardoso, 1921, 170 e seg.), que antes se toma a decisão que resolve a contenda e, depois, se dá a razão; dada a variedade das normas e o grande arsenal de técnicas argumentativas que séculos de dialética, jurídica ou não, forjaram, não é difícil motivar decisões, mesmo amplamente diversas sobre o mesmo objeto, como as crônicas judiciárias confirmam.

\section{Evoluçáo legislativa do agravo de instrumento: do CPC-1973 ao CPC-2015}

Ao longo das últimas décadas, mais precisamente desde a vigência do CPC-1973 até sua revogaçáo pelo código de 2015, importantes mudanças relativas ao agravo de instrumento foram introduzidas na legislação de regência. De início, destaca-se que, ao entrar em vigor, o CPC-1973 previa que o agravo de instrumento devia ser interposto no primeiro grau de jurisdição e seguia procedimento que requeria a formaçáo das peças a serem instrumentalizadas, bem como ouvida da parte contrária. Em sucessivo, o juiz - de primeiro grau - fazia o juízo de retratação e remetia os autos ao tribunal ad quem, quando não reformava a decisão agravada. $\mathrm{O}$ rito era tăo moroso que a jurisprudência passou a admitir, de forma pacífica, o uso do mandado de segurança para atribuir efeito suspensivo ao agravo de instrumento. Tal sistemática, com acerto, teve de ser modificada.

A primeira alteração legislativa relevante ocorreu no ano de 1995, com a entrada em vigor da lei no 9.139 , que introduziu no ordenamento jurídico, entre outras novidades, a possibilidade de o relator do agravo de instrumento atribuir a tal recurso efeito suspensivo, prescindindo-se da ação de mandado de segurança, nas hipóteses previstas no art. 558 do código entấo vigente. Além disso, permitiu que o relator pudesse conceder ao agravo instrumentalizado o chamado "efeito ativo", que nada mais é do que adiantamento, total ou parcial, da tutela recursal negada em primeiro grau, nos termos do art. 527, III, do CPC-1973 (CARNEIRO, 2006, p. 11). Desde então, deixou de ser admissível o uso do 
mandado de segurança para se emprestar efeito suspensivo ao agravo de instrumento, pois tal recurso passou a ser interposto diretamente no segundo grau e o relator respectivo passou a poder deferir o efeito suspensivo no âmbito do próprio recurso. Passou-se a fazer num único processo (agravo de instrumento) o que, até então, requeria dois: o agravo de instrumento no primeiro grau e o mandado de segurança no segundo.

Contudo, deve-se destacar que o art. 558 do CPC revogado, em sua redaçáo original, taxava as hipóteses nas quais o agravo de instrumento teria efeito suspensivo, como observa Teresa Arruda Alvim Wambier (2006, p. 351). O agravo de instrumento só podia ter efeito suspensivo naquelas hipóteses rigorosamente elencadas pela antiga redaçáo do art. 558. Nesse sistema inicial tanto o relator quanto o próprio juiz da causa podiam atribuir efeito suspensivo ao agravo. Entretanto, se tal possibilidade tivesse logrado eficácia a lei não careceria de alteração, até porque se o próprio juiz da causa foi quem deferiu a decisão agravada a sua suspensão era pouquíssimo provável. Por sua vez, o relator do agravo só tomava conhecimento da causa após todo o trâmite de primeiro grau, que demandava tempo razoável para ser concluído, não se prestando, consequentemente, para resolver situaçôes de urgência. Daí o porquê de o mandado de segurança ter sido o meio mais eficaz para a obtenção do efeito suspensivo.

Assim, a alteração introduzida na sistemática do agravo de instrumento pela lei no 9.139/1995, que permitiu sua interposição diretamente no tribunal ad quem, diferentemente do que ocorria até então, foi fundamental para dotar o procedimento desse recurso de celeridade e, via de consequência, de eficácia e eficiência processual. Havia, portanto, uma desnecessária burocracia no procedimento do recurso de agravo de instrumento na primeira instância, à medida que o juiz da causa iria, como consigna Carreira Alvim (1996, p. 100): “... recebê-lo, processá-lo e também julgá-lo, dado que podia exercer o juízo de retratação. Só era encaminhado ao tribunal pelo escrivão, se mantida a decisão ou, se reformada, houvesse pedido do agravado”.

Tal mudança visou, precipuamente, conferir celeridade e eficiência no processamento e julgamento do agravo de instrumento, com o escopo de evitar que, "(...) não viesse a ser julgado, no tribunal, quando já houvesse a causa sido decidida na inferior instância." (ALVIM, 1996, p. 43).

Ainda no tocante às alterações legislativas relativas ao recurso de agravo no ordenamento processual pátrio, também merecem destaque as importantes modificaçóes trazidas pela lei no 10.352 , de 26 de dezembro de 2001, cuja vigência se deu a partir de 27 de março de 2002. Dentre tais modificaçôes, tem-se, primeiramente, o estabelecimento do prazo de 10 dias para a resposta da parte agravada nos casos de interposiçáo de agravo retido, posto que seria inconcebível, como acontecia até tal mudança, que o prazo para a parte agravante interpor tal recurso fosse de 10 dias, enquanto o prazo para o agravado responder fosse de apenas cinco dias (VIANA, 2016). 
Outra alteração relevante promovida pela mesma lei no 10.352/2001 consistiu na alteração do conteúdo do inciso II do art. 527 do CPC-1973, que facultou ao relator do agravo de instrumento, no tribunal, determinar a sua conversão em agravo retido, exceto nas hipóteses de provisão jurisdicional de urgência ou quando tal conversão pudesse impor à parte agravante lesão grave e de difícil ou incerta reparação. $\mathrm{O}$ agravo retido, então, passou a ser o recurso-regra a ser interposto contra as interlocutórias de primeira instância. Segundo Athos Gusmão Carneiro (2006, p. 11), o agravo retido deixou de ser manejado como mera opção do recorrente, mas tornou-se obrigatório nas hipóteses em face das quais não havia previsão expressa de cabimento de agravo de instrumento.

A finalidade de tal modificação não era outra que não a diminuição do número de agravos instrumentalizados interpostos perante os tribunais, na tentativa de desafogar o poder judiciário de segundo grau, embora sem muito sucesso (VIANA, 2016). Comprovando tal assertiva, em 2005, a redação do inciso II do artigo 527 foi novamente alterada, desta vez pela lei no $11.187 / 2005$, como será observado mais adiante.

Por fim, outra importante modificação trazida pela lei no $10.352 / 2001$ foi a criação do parágrafo único do art. 526 do CPC-1973, que previa a inadmissibilidade do recurso de agravo se o agravante, no prazo de três dias, náo apresentasse, perante o juízo da instância originária, cópia da petição do agravo e da comprovação de que foi interposto.

Pois bem, no andar das reformas do agravo de instrumento, no ano de 2005, com a entrada em vigor da lei no 11.187 , de 19 de outubro daquele ano, ocorreram as últimas alteraçóes relativas ao instituto em questão antes da entrada em vigor do CPC-2015. Essa lei de 2005 visou à correção de erros que haviam resistido às alterações anteriores, bem como deu mais importância ao agravo retido, que passou a ser, de fato, a regra cabível na maioria dos casos de impugnação de decisóes interlocutórias no primeiro grau de jurisdição, deixando o agravo de instrumento, nas palavras de Athos Gusmão Carneiro (2006, p. 11), apenas “... para os casos de provimentos judiciais de urgência, capazes de resultar em prováveis danos graves".

Por fim, a lei no $11.187 / 2005$ modificou a redação do parágrafo único do art. 527 do CPC-1973, para estabelecer a regra da irrecorribilidade da decisão do relator que convertia o agravo de instrumento em retido, bem como a decisão do relator que suspendia a eficácia da decisão agravada - concedendo efeito suspensivo ao agravo - ou que antecipava a tutela recursal - concedendo o chamado efeito ativo (CARNEIRO, 2006, p. 21).

Com a entrada em vigor do CPC-2015, o recurso de agravo de instrumento sofreu profundas alteraçóes. Os recursos retidos foram extintos, ou seja, não apenas o agravo, mas, igualmente, o recurso extraordinário e o recurso especial, e a irrecorribilidade das decisóes interlocutórias de primeiro grau passou a ser a regra. $\mathrm{O}$ art. 1.015 do novo 
código de processo tencionou estabelecer um rol taxativo para o cabimento do agravo de instrumento, embora tenha falhado visceralmente quando não previu o seu cabimento em face da decisão do juiz que rejeita alegação de incompetência absoluta, embora o tenha previsto para a rejeição da alegação de convenção de arbitragem, fato que forçou o Superior Tribunal de Justiça a corrigir tal equívoco. Com efeito, o STJ passou a admitir o cabimento do agravo de instrumento também para as hipóteses de alegação de incompetência do juiz, incluindo os casos nos quais a intervenção de terceiros possa influir na questão da competência (BRASIL, STJ, REsp no 0006880-94.2017.8.16.0000 $-22 / 02 / 2019)$.

A adoção da regra da irrecorribilidade das interlocutórias de primeiro grau, por sua vez, proporcionou a ampliação do efeito devolutivo da apelação, já que as decisóes inatacáveis por agravo de instrumento tornaram-se impreclusas, devendo ser alegadas em preliminar de razóes ou contrarrazóes de apelação, como prevê o art. $1009, \$ 1^{\circ}$ do CPC-2015. O CPC/2015 manteve a regra do cabimento do agravo de instrumento diretamente no tribunal ad quem (art. 1.016). No pertinente às peças obrigatórias, o rol anteriormente previsto no art. 525, I, do CPC-1973 foi ampliado, como se constata pelo quadro comparativo a seguir, vejamos:

\begin{tabular}{|l|l|}
\hline \multicolumn{1}{|c|}{ CPC-1973 } & \multicolumn{1}{|c|}{ CPC-2015 } \\
\hline $\begin{array}{l}\text { Art. 525, A petiçáo de agravo de instrumento será } \\
\text { instruída: }\end{array}$ & $\begin{array}{l}\text { Art. 1.017. A petiçáo de agravo de instrumento } \\
\text { será instruída: } \\
\text { I - obrigatoriamente, com cópias da decisão } \\
\text { agravada, da certidão da respectiva intimação e } \\
\text { das procuraçóes outorgadas aos advogados do } \\
\text { agravante e do agravado; } \\
\text { da contestação, da petição que ensejou a decisão } \\
\text { agravada, da própria decisão agravada, da certidão } \\
\text { da respectiva intimaçáo ou outro documento oficial } \\
\text { que comprove a tempestividade e das procuraçóes } \\
\text { outorgadas aos advogados do agravante e do } \\
\text { agravado; }\end{array}$ \\
$\begin{array}{l}\text { II - com declaração de inexistência de qualquer } \\
\text { dos documentos referidos no inciso I, feita } \\
\text { pelo advogado do agravante, sob pena de sua } \\
\text { responsabilidade pessoal; }\end{array}$ \\
\hline
\end{tabular}

As cópias da petição inicial, da contestação, da petição que ensejou a decisão agravada náo constavam do CPC antecedente como peças obrigatórias e, agora, passam deter essa natureza, exceto se o processo for eletrônico, caso em que as peças previstas nos incisos I e II não serão exigidas, posto que o tribunal terá acesso integral aos autos. Ademais, a ausência de qualquer delas não mais acarretará o não conhecimento imediato do recurso, como ocorria no regime anterior, considerando que o art. $1.017, \$ 3^{\circ}$, associado ao art. 932, estatuem que o relator deve conceder ao agravante o prazo de 5 (cinco) dias para que seja sanado vício ou complementada a documentação exigível, antes de considerar o recurso inadmissível. 
Em relação ao dever de informar ao juízo de primeiro sobre a interposição do agravo de instrumento, o art. 1.018 do CPC-2015 o trasmudou em mera faculdade do agravante, exceto se os autos não forem eletrônicos, caso em que continua a deter natureza de dever processual, devendo o recorrente requerer a juntada, aos autos do processo, de cópia da petição do agravo de instrumento, do comprovante de sua interposição e da relação dos documentos que instruíram o recurso, no prazo de três dias.

Quanto ao juízo de retratação, o art. 1.018, \$ 1º do CPC-2015 esclarece que "Se o juiz comunicar que reformou inteiramente a decisão, o relator considerará prejudicado o agravo de instrumento”. A retratação possui natureza de nova decisão interlocutória de índole desconstitutiva, sendo agravável pela parte favorecida pela decisão anterior e desfavorecida pela decisão subsequente. Esse aspecto relativo à recorribilidade da decisão de retratação preexistia na sistemática do CPC-1973. A propósito, Luis Franzé (2005, p. 140) consigna, que: "O eventual exercício do juízo de retratação (desde que não ponha termo ao processo) será decisão interlocutória e, por consequência, desafiará a interposição de novo agravo pelo prejudicado”.

\section{Do cabimento do agravo de instrumento}

As decisóes interlocutórias, que no CPC-1973 eram consideradas como aquelas pelas quais o juiz, no curso do processo, resolvia questáo incidente, isto é, questão de natureza processual, passou a ser conceituada por exclusão no art. $203, \S 2^{\circ}$, do CPC2015, como todo pronunciamento judicial de natureza decisória que não se enquadre no conceito de sentença (terminativa ou definitiva). Pois bem, o agravo de instrumento é o recurso que desafia as decisóes interlocutórias, ou seja, contra os atos pelos quais o juiz, no curso do processo, profere decisão não enquadrada no conceito de sentença. Para Amaral Santos (1985, p. 129): "Chama-se agravo porque é recurso destinado a impugnar ato decisório do juiz, causador de gravame ou prejuízo ao litigante, e de instrumento porque, diversamente dos demais recursos, não se processa nos próprios autos em que foi proferida a decisão impugnada, mas sim em autos apartados...”.

Porém, a denominação atribuída ao ato judicial que não encerra a fase de cognição (com ou sem resolução de mérito) é irrelevante para o cabimento do agravo de instrumento. O que, de fato, importa é se tal ato judicial acarreta, ou não, prejuízo a uma das partes ou a terceiros, pois sendo positiva a resposta contra ele caberá o agravo. Ademais, Gediel Araújo Júnior (2002, p. 23) adverte para um aspecto que comprova essa asserção, o qual consiste no fato de alguns atos judiciais intitulados de "despachos" trazerem em seu conteúdo textual verdadeiras decisões judiciais, as quais, por óbvio são agraváveis conquanto a equivocada denominação. 
Com efeito, não interessa a denominação epigrafada pelo juiz no ato decisório interlocutório, isto é, mesmo que intitulado de despacho sempre que o ato judicial trouxer conteúdo decisório que não resulte na extinção da fase cognitiva da demanda, dele caberá agravo de instrumento (ARAÚJO JÚNIOR, p., 2002, p. 23). Na doutrina construída sob a égide do CPC-1973, parte da doutrina defendeu que os despachos não poderiam ser recorríveis, mas sujeitos à correição parcial, reclamação ou mandado de segurança. Nesse sentido, Ivan de Hugo Silva (1997, pp.22-23) afirmara:

Partindo do princípio de que o despacho de mero expediente não cabe recurso, porém, tendo em vista ocasionarem os mesmos, às vezes, violaçóes de direitos das partes, compreende-se como um mal necessário o uso de correiçóes parciais, reclamaçóes e mesmo mandado de segurança, visando sanar os efeitos dos erros cometidos, trazendo soluções no campo prático, ainda que carentes de respaldo legal.

Acontece que no regime do CPC-2015, somente as decisóes interlocutórias expressamente previstas no art. 1.015, bem como aquelas posteriormente admitidas pelo STJ, como a questão relativa à competência, é que são susceptíveis de impugnação pela via do agravo de instrumento, restando as demais submetidas ao crivo da apelação.

Essa situação agrava o problema das decisóes interlocutórias omissivas, porquanto não há previsão de seu cabimento no art. 1.015 e, por outro lado, os casos de tutela provisória de urgência não decididos na primeira instância não podem quedar-se a espera do julgamento da apelação, sob pena de perda inexorável de seu respectivo objeto, pois, como observou Athos Gusmáo Carneiro (2005, p. 20) “... o propósito da tutela antecipada é, com efeito, superar de imediato os possíveis efeitos deletérios ao direito da parte, decorrentes do tempo em que o processo corre (ou lentamente marcha...) em juízo".

Athos Gusmão Carneiro pontua que a apreciação tardia da tutela de urgência importa em seu indeferimento, assim como acontece com a negativa de intervenção de terceiros - o assistente, por exemplo - pois neste caso de nada adiantaria ao terceiro uma assistência deferida apenas por ocasião da apelação, quando o processo já terá sido julgado (CARNEIRO, 2005, p. 21). Tais situações impóem a reflexão sobre a necessidade de construção de uma interpretação no sentido de que a omissão ou postergaçáo judicial na apreciação de requerimento de tutela provisória de urgência implica seu indeferimento, logo a interpretaçáo mais garantista do ponto de vista do acesso à justiça consiste na que considera que essas hipóteses estão enquadradas no conceito de decisão interlocutória denegatória. Passemos à questão do enquadramento dessa situação processual no conceito de decisão interlocutória. 


\section{Enquadramento da omissáo judicial no conceito de decisão interlocutória}

Como visto alhures, em muitos casos existe para a parte autora de uma demanda judicial a necessidade de uma prestação jurisdicional urgente. Nesses casos, não há outro caminho que não seja, desde quando da propositura, requerer-se a concessão liminar inaudita de tutela provisória de urgência (cautelar ou antecipada, antecedentes), levandose ao conhecimento do poder judiciário, nessa ocasiáo, todos os elementos fáticos e legais que justifiquem tal pedido, notadamente a existência dos requisitos específicos exigidos em lei, isto é, os "elementos que evidenciem a probabilidade do direito e o perigo de dano ou o risco ao resultado útil do processo", consoante a letra do caput do art. 300 do CPC-2015.

Assim, preenchidos tais requisitos, não há dúvidas de que assiste à parte autora o direito subjetivo de ver concedida a medida liminar requerida na peça exordial. Por outro lado, se o magistrado de primeiro grau não se convencer acerca da presença dos requisitos autorizadores para o deferimento da medida liminar, deve indeferir o requerimento, abrindo espaço para que a parte autora, dada a urgência da situação, possa manejar o recurso de agravo de instrumento para o tribunal ad quem, na tentativa de reformar a decisão agravada. Nesse caso, o indeferimento é expresso, distintamente da situação que constitui o nosso objeto problematizado.

Porém, quando o juiz não indefere o pleito liminar explicitamente, mas se reserva para apreciá-lo após a formação do contraditório, o que ocorre, de fato, é, igualmente, uma denegação, indeferimento, contudo implícito. $\mathrm{O}$ náo pronunciamento imediato do juízo deve ser interpretado não como um simples despacho de mero expediente, mas sim como uma decisão interlocutória indeferitória, posto consistir em inequívoca negação da prestação da tutela jurisdicional, dever ao qual o juiz não pode se abster, mormente em face da imposição prevista no art. 489, IV, do CPC-2015. Esse dispositivo considera não fundamentada a decisão judicial, que "não enfrentar todos os argumentos deduzidos no processo capazes de, em tese, infirmar a conclusão adotada pelo julgador”.

Por óbvio, a regra aplica-se também aos requerimentos de tutela provisória de urgência, já que o $\$ 1^{\circ}$ do art. 489 explicita que esse dever aplica-se a “... qualquer decisão judicial, seja ela interlocutória, sentença ou acórdão...”. Logo, a abstenção judicial deve ser equiparada a uma decisão interlocutória denegatória, sujeita, portanto, ao manejo do agravo de instrumento. Cuida-se de decisão não fundamentada, diante do disposto no art. $489, \$ 1^{\circ}$, do CPC-2015, não se tratando de decisão incompleta, mas de simples e mera omissão. Sem dúvida, o ato de não decidir um requerimento de tutela de urgência consiste numa decisão negativa, a qual também pode ser questionável através de embargos declaratórios, como muito bem observou Teresa Wambier (2005, p. 104). Ocorre que, na 
espécie aqui tratada, os aclaratórios seriam de pouquíssima utilidade e podem, inclusive, agravar a situação de perigo de dano ou de risco ao resultado útil do processo.

Ainda a respeito do tema, merecem destaque também as ponderaçóes de Montenegro Filho (2007. v. 2. p. 439-450), que toma como exemplo caso hipotético de internamento em hospital privado, aliado à negativa por plano de saúde de autorização para permanência de paciente no estabelecimento. Nesse caso, se o magistrado de primeiro grau, por circunstância qualquer, não enfrentar o pedido de tutela de urgência, na verdade, estará a negar a tutela.

Outro relevante argumento apontado por Montenegro Filho (2007. v. 2. p. 439450) é que a não apreciação do requerimento pode dar ensejo ao perecimento do próprio direito material buscado, ao que podemos acrescentar que fulminado estaria o objeto do processo em razáo da inércia do julgador de primeiro grau. Além dos argumentos e posicionamentos acima transcritos, observa-se também que alguns tribunais se posicionavam, ainda sob a égide do CPC-1973, no sentido do cabimento do agravo de instrumento em tais casos, desde que configurada a urgência da prestação jurisdicional, como restará demonstrado a seguir. A admissão do cabimento do agravo de instrumento em tais situaçóes constitui posição garantista do acesso à justiça, porquanto, como anotou com precisão Teresa Wambier, sempre que o juiz não apreciar uma questão relevante posta pela parte haverá omissão judicial, a qual se submete ao crivo da revisão recursal (WAMBIER, 2005, pp. 351-352).

\section{Tratamento pretoriano da matéria}

Durante a vigência do CPC-1973 percebeu-se uma crescente aquiescência da jurisprudência no sentido do cabimento do agravo de instrumento em situaçóes de omissão judicial relativas à apreciação de requerimento de tutela de urgência. Nesse sentido, o Tribunal de Justiça do Estado de Pernambuco (BRASIL, TJPE - AI - Processo no 63694-2. Relator: Desembargador Jones Figueiredo. Órgão Julgador, 2001) já decidiu que

A imediatidade de um provimento jurisdicional, a saber do art. 273 do CPC, não pode, ao livre talante do magistrado, ser postergada para outro momento, com sacrifício do próprio direito material, enquanto não prestada a tutela de urgência. Postergando o juiz o devido exame a respeito e o prazo dessa omissão, com os eventuais acréscimos advindos do próprio mecanismo processual pertinente, representa dilação incabível, a implicar, inevitavelmente, em denegação da justiça.

A tese pelo cabimento do agravo de instrumento em razão da omissão judicial na apreciação de requerimento de tutela de urgência fortalece-se no CPC-2015, sobretudo, em razão do dever-princípio da cooperação intersubjetiva dos sujeitos processuais, previsto no art. $6^{\circ}$, o qual também recai sobre o juiz considerando que o dispositivo pontua que: 
"Todos os sujeitos do processo devem cooperar entre si para que se obtenha, em tempo razoável, decisão de mérito justa e efetiva”. Assim, adota-se a premissa de que pleitos de natureza urgente impóem análise igualmente expedita. Nessa precisa senda, a Corte Especial do Superior Tribunal de Justiça já concebeu que “... A antecipação de tutela, assim como as medidas liminares (vinculadas aos pressupostos da plausibilidade jurídica e do perigo na demora), tem exame célere, dada a urgência natural da demanda, prescindindo de prévia oitiva da parte contrária” (BRASIL, STJ, Agravo regimental na suspensão de liminar e de sentença no 18/RJ. Relator: Ministro Edson Vidigal. Órgão Julgador: Corte Especial. Data do Julgamento: 25/10/2004. Publicação: DJ, 06/12/2004).

Esse posicionamento do Superior Tribunal de Justiça bem espelha o lastro pretoriano que estabelece verdadeiro dever processual ao magistrado de primeiro grau de analisar incontinenti requerimentos urgentes, não podendo se invocar em tais situaçóes a regra do art. 226 do CPC-2015, que faculta ao juiz o prazo de cinco dias para proferir despachos e dez dias para prolatar decisão interlocutória. Agrega-se à tese, o preceito constitucional estabelecido no art. 93, XII, da Constituição Federal, que considera que a atividade jurisdicional é ininterrupta, devendo manter à disposição dos jurisdicionados plantão permanente precisamente para apreciação imediata de casos urgentes.

Ademais, mesmo que náo se admita que o ato judicial omissivo na apreciaçáo de requerimento de tutela provisória de urgência enquadre-se no conceito de decisão interlocutória, mas sim no de despacho, já que nele não se vislumbra decisão explícita, mesmo assim esse "despacho" seria, igualmente, recorrível. Nesse sentido, o Superior Tribunal de Justiça considera que são recorríveis os despachos de mero expediente, desde que capazes de causar à parte gravame ou prejuízo (BRASIL, STJ - REsp 365023 MG 2001/0110562-8). Note-se que o panorama dogmático no qual o STJ assentou tal entendimento tomou por base o art. 504 do CPC-1973, que dizia que dos despachos não cabe recurso. Assim, a reiteração desta regra no art. 1.001 do CPC-2015, por óbvio, não obsta o conhecimento do recurso de agravo de instrumento também na nova sistemática processual. Sempre que um pronunciamento judicial acarretar prejuízo às partes ou a terceiros será susceptível de recurso, incluindo, por conclusão silogística, a decisão que omissiva em questão.

\section{Consideraçóes finais}

Restou demonstrado que, durante a vigência do CPC-1973, parte da doutrina e da jurisprudência admitia o cabimento do agravo de instrumento em situaçóes nas quais o juiz de primeiro grau reservar-se para apreciar requerimento de concessão de tutela de urgência após a manifestação do réu. 
Conquanto o CPC-2015 tenha optado pela taxatividade, quanto ao cabimento do agravo de instrumento sem contemplar a situação jurídica representada pela omissão judicial na apreciação de requerimento de tutela provisória de urgência, mesmo não havendo previsão expressa de recorribilidade para essa hipótese, o entendimento pretoriano que admitia o agravo na sistemática antecedente deve manter-se com supedâneo no princípio do acesso à justiça e da inafastabilidade da proteção jurisdicional (CF, art. 5º, XXXV).

Ademais, conclui-se que tal atitude judicial omissiva não pode ser enquadrada no gênero dos despachos desprovidos de conteúdo decisório em razão do prejuízo imediato que irradia, cuida-se, inegavelmente, de ato judicial dotado de carga decisória implícita porquanto implica negação da pretensão autoral e pode gerar a consequência da perda de objeto do processo, sobretudo quando a prestaçáo a ser adotada pela parte ré for de cunho instantâneo e satisfativo, como sói acontecer com os requerimentos de tutela de urgência em decorrência de recusa de planos de saúde em autorizar tratamentos medicocirúrgicos de urgência.

Nesses casos, a prestação tardia do serviço jurisdicional é inservível ao jurisdicionado, e, se concedida a destempo, nenhum efeito prático trará, será inócua. A não apreciação tempestiva de requerimentos de tutela provisória de urgência, além de malferir os princípios processuais citados acima, apresenta-se como inequívoco atentado contra a garantia constitucional da razoável duração do processo (CF, art. $5^{\circ}$, LXXXVIII).

Ao fim e ao cabo, é preciso apontar a possibilidade de, após a interposição do agravo de instrumento, o relator também resolver reservar-se para apreciar o pleito de concessão de efeito ativo somente após a formação do contraditório no âmbito do procedimento do agravo instrumentalizado, nesse caso estará a concorrer para perpetuar a situação verificada no primeiro grau, sendo, tal decisão, também recorrível imediatamente através do recurso de agravo interno (CPC-2015, art. 1.021). No caso não é mais admissível o agravo regimental, considerando que o art. 1.021 ampliou o cabimento do agravo interno, o qual no regime do CPC-1973 restringia-se às decisóes monocráticas dos relatores de natureza terminativa, isto é, que extinguiam recursos ou açóes de competência originária dos tribunais. Entretanto, o art. 1.021 do novo código prevê o cabimento do agravo interno para qualquer decisão individual proferida pelo relator, inclusive as terminativas, fulminando, assim, a razão de ser do agravo regimental.

\section{Referências}

ALVIM, José Eduardo Carreira. Novo agravo: lei no 9.139, de 30/1 1/95. Belo Horizonte: Del Rey, 1996. 
ARAGÃO, Egas Dirceu Moniz de. Do agravo regimental. São Paulo: Revista de Direito Processual Civil - Saraiva, v. 2, n. 3, jan./jun., 1961.

ARAUJO JÚNIOR, Gediel Claudino de. Recurso de agravo: teoria e prática. 4. ed. São Paulo: Atlas, 2002.

AUGUSTO, Antônio Rodrigues de Lemos. Agravo de instrumento: a eterna polêmica. Jus Navigandi, Teresina, ano 9, n. 730, 5 jul. 2005. Disponível em: http://jus2.uol.com. br/doutrina/texto.asp?id=6960>. Acesso em: 20 mar. 2016.

BOBBIO, Norberto, MATTEUCCI, Nicola e PASQUINO, Gianfranco. Dicionário de politica. 4. ed. V. 2. Trad: VARRIALLE, Carmen C. et. al. Brasília: UNB, 1983.

BRASIL. Lei no 5.869/1973.

BRASIL. Lei no 13.105/2015.

BRASIL. STJ, REsp no 0006880-94.2017.8.16.0000 - 22/02/2019.

BRASIL. TJPE - AI - Processo no 63694-2 - 2001.

BRUM, Jander Maurício. Agravo. Inovações. Comentários. 2. ed. Rio de Janeiro: Aide, 1997.

CARNEIRO, Athos Gusmão. Do recurso de agravo ante a lei no 11.187/2005. Revista Jurídica: Órgão Nacional de Doutrina, Jurisprudência, Legislação e Crítica Judiciária, Porto Alegre, Ano 54, n. 339, janeiro de 2006.

CARNEIRO, Athos Gusmão. Da antecipação de tutela. 6. ed. Rio de Janeiro: Forense, 2005.

CARVALHO, Fabiano. Reflexão sobre o instrumento do agravo: peças obrigatórias, facultativas, necessárias e úteis. São Paulo: Escola Paulista de Direito, maio/2006. Disponível em: <http://www.epdireito.com.br/epd/publier4.0/dados/anexos/259_3. pdf $>$. Acesso em: 18 fev. 2016.

CASTRO, Marcos Valério Melo. A desnecessidade de autenticação das cópias das peças que obrigatoriamente instruem o recurso de agravo de instrumento. Uma crítica à visão formalista do processo. Jus Navigandi, Teresina, ano 6, n. 59, out. 2002. Disponível em: http://jus2.uol.com.br/doutrina/texto.asp?id=3270. Acesso em: 18 out. 2016.

DIDIER JÚNIOR, Fredie Souza. Primeiras impressóes sobre o parágrafo único do art. 526 do CPC. Jus Navigandi, Teresina, ano 6, n. 57, jul. 2002. Disponível em: http:// jus2.uol.com.br/doutrina/texto.asp?id=2983. Acesso em: 18 fev. 2016.

FRANZÉ, Luís Henrique Barrante. Agravo: frente aos pronunciamentos de primeiro grau no processo civil. 3. ed. Curitiba: Juruá, 2005. 
MACIEL, Rafael Fernandes. A lei no 10.352/01 e a possibilidade de declaração de autenticidade no agravo de instrumento do art. 522. Jus Navigandi, Teresina, ano 6, n. 59, out. 2002. Disponível em: http://jus2.uol.com.br/doutrina/texto.asp?id=3218. Acesso em: 18 out. 2016.

MONTENEGRO FILHO, Misael. Possibilidade de interposição do agravo de instrumento contra ato omissivo do magistrado. In: DUARTE, Bento H.; DUARTE, Ronnie Preuss (Coord.). Processo civil: aspectos relevantes. São Paulo: Método, 2007.

NEGRÃO, Theotonio. Código de processo civil e legislação processual em vigor. 30. ed., São Paulo: Saraiva, 1999.

NERY JUNIOR, Nelson; NERY, Rosa Maria de Andrade. Código de processo civil comentado. 9. ed. Sáo Paulo: Editora Revista dos Tribunais, 2006.

NERY JÚNIOR, Nelson \& WAMBIER, Teresa Arruda Alvim: Coords. Aspectos polêmicos e atuais dos recursos cíveis de acordo com a lei 10.352/2001. São Paulo: Revista dos Tribunais, 2002.

NEVES, Frederico Ricardo de Almeida. Agravo. Nova sistemática. E outros temas de exegese controvertida da reforma processual civil. Recife: Bagaço, 1996.

SANTOS, Moacyr Amaral. Primeiras linhas de direito processual civil. 3. V. 8. ed. São Paulo: Saraiva, 1985.

SILVA, Ivan de Hugo. Agravos no novo código de processo civil. Rio de Janeiro: Aide, 1977.

SOUZA, Bernardo Pimentel. Introdução aos recursos cíveis e à ação rescisória. 10. ed. São Paulo: Saraiva, 2014.

WAMBIER, Teresa Arruda Alvim. Os agravos no CPC brasileiro. 4. ed. São Paulo: Editora Revista dos Tribunais, 2006.

WAMBIER, Teresa Arruda Alvim. Omissão judicial e embargos de declaração. São Paulo: Revista dos Tribunais, 2005. 